\title{
The Analysis Of Bima And English Language Pronouns
}

\author{
Waliyudin \\ Prodi Pendidikan Bahasa Inggris STKIP Taman Siswa Bima \\ waliyudinkhalik@gmail.com
}

\begin{abstract}
The focus of this study was attempt to describe and contrast the aspect and the use of pronouns. The design of this study belongs to qualitative descriptive study. It refers to the following criteria: (1) having one natural setting as the data sources, (2) using the researcher as the key instrument, (3) having much concern with the process rather than the outcomes, (4) being descriptive in nature, (5) having much concern with the utterances or words as the analysis of the data rather than numbers, and (6) analyzing the data inductively. This result show the personal pronoun in English and Bima language there are divided forms based on singular and plural. Meanwhile English differentiated how using based on subject /object in sentence. even gender for example "he" male or"she" female. whereas In bima are not differentiated based on object or female and male but the using personal pronoun in Bima just differentiated from added clit for change form singular to plural and personal pronoun in Bima would change use based on situation, and who are talking to? That's mean using personal pronoun in Bima were influenced by cultural system, class formal and either polite.
\end{abstract}

Keywords: Pronoun, Bima Language and English Language.

\section{PENDAHULUAN}

Languages as the human's spoken and written communications instrument and communications system are separate all over the world since unpredictable time ago, in which are different in every countries, and ethnics, such as in Indonesia, English, Arabic, Japan, etc. similar to P. J. W Nababan (1983), the spoken languages in Indonesia fall into three classes; 1) Indonesian or Bahasa Indonesia, 2) Local Language, and 3) Foreign Language.

English as a Foreign language that used in Indonesia is currently the most used language in the world. This has been extensively studied. English is a family IndoEuropean languages consisting of 53 languages and including one member of IndoEuropean languages Narranmase (2010).

Bima language is one of the topten of the greatest speaker's number of local languages in Indonesia. Bima language speakers also are not only lives in one corner of Bima City, but they are separate in all over the island. Speakers of language Bima is estimated at 608,679 people Debdikbud (1996).

Jurnal Ilmu Sosial dan Pendidikan
These two languages above come from different families, they have a structure apart from that, two languages are also influenced by cultural system such as social factors that are status, age, gender, and economic ability.

Nowadays Bima language speaking community is among children, teenagers and even adults pay less to the cultural system. When communicating makes the researcher interested and choosing personal pronouns in particular in English and Bima as objects to be researched Jafar, Syamsinas (2004).

Personal pronouns are words used to replace forms which designates the speaker or listener or noun group Blomfield (1933). Many languages substitute second personal accordingly with different social relations between speakers and listeners.According to Aarts and Aarts, (1982). The researcher in this case wiil research about personal pronoun both language English and Local language of Indonesia is Bima language based on their function, form what the differences and similarities.

\section{METODE PENELITIAN}


The qualitative research attempts to arrive data rich description of people, objects, events, places, conversations, and so on Bugin, M (2010). In this research, the data was the script of conversations of society in Bima. The research was conducted at Bima that located at West Nusa Tenggara (NTB) Indonesia and conducted for 3 month. The researcher categorized the sample or the object of this research into 3 group conversation, they are: children, academician degree-holders, and common society. In take the sample, the researcher have 2 indicators to chosen the sample there are a) Pure inherit of Bima and b) Domicile at Bima.

There are sources of data are primary data and secondary data, primary data by taken videos conversation of Bima Society, there are 3 videos conversation; children, academician and common society. Secondary data is taken form what the differences and similarities. The researcher applies 3 items as technique of collecting data: (1) observation (2) recording and (3) interviews. After collecting the data the researcher analyzed the data in the following steps: (1) watch the videos conversation (2) transcript the videos (3) Note the types of personal pronoun that create in daily conversation used by Bima's society (4) The researcher connects the data with the theories about types of personal pronoun (5) Classified the types personal pronoun that create in daily conversation used by different level of Bima's society and then chosen or take the differences and similarities create in daily conversation used by different level of Bima's society (6) Finally, researcher draws the conclusion based on the result.

\section{HASIL DAN PEMBAHASAN (12pt)}

Table 1. In this table present the English personal pronouns and their form

\begin{tabular}{|c|c|c|c||}
\hline English Personal pronoun \\
\hline \multirow{4}{*}{ Subject } & Object & \multicolumn{2}{|c|}{ Information } \\
\hline \multirow{4}{*}{ singular } & $\mathrm{I}$ & $\mathrm{Me}$ & Saya. \\
\cline { 2 - 5 } & You & You & $\begin{array}{c}\text { Kamu, anda, } \\
\text { engkau. }\end{array}$ \\
\cline { 2 - 5 } & $\mathrm{He}$ & Him & Dia (laki-laki) \\
\cline { 2 - 4 } & She & Her & Dia (perempuan) \\
\hline \multirow{3}{*}{ plural } & We & Us & Kami \\
\cline { 2 - 5 } & You & You & Kalian \\
\cline { 2 - 4 } & They & Them & Mereka \\
\hline
\end{tabular}

Table 2. In this table present Bima personal pronouns and their forms.

\begin{tabular}{|c|c|c|}
\hline $\begin{array}{l}\text { Personal } \\
\text { pronoums }\end{array}$ & singular & plural \\
\hline Orang Pertama & $\begin{array}{l}\text { 1. Nahu } \\
\text { 2. Mada } \\
\text { 3. Nalku } \\
\text { 4. Wekiku } \\
\text { ( Aku, Saya) }\end{array}$ & $\begin{array}{l}\text { 1. Nami } \\
\text { 2. MadaDoho } \\
\text { (Kami) }\end{array}$ \\
\hline Orang kedua & $\begin{array}{l}\text { 1. Nggomi } \\
\text { 2. Nggou } \\
\text { 3. Ita } \\
\text { 4. Ndaimu } \\
\text { 5. Ndaita } \\
\text { (Kamu, } \\
\text { Anda, } \\
\text { Engkau) }\end{array}$ & $\begin{array}{l}\text { 1. Nggomidoho } \\
\text { 2. Itadoho } \\
\text { 3. Ndaidohom } \\
\text { 4. Ndaidohota } \\
\text { (kalian semua. } \\
\text { Anda } \\
\text { sekalian) }\end{array}$ \\
\hline Orangketiga & Sia (Dia) & Sia doho \\
\hline
\end{tabular}

\section{Discussion}

Based on the finding of Research above that are the tables Analyzed of personal pronouns in English and Bima language. They have same functions and same forms:

\section{Forms, function and how using of personal pronouns in English}

Form of personal pronouns "I" it is as Subject in Sentences. That's meaning as First personal pronoun (singular).

Form of personal pronoun "me" it is as a object in the sentence. That's mean as first personal pronoun (singular).

Form of personal pronoun "you" it is a subject and also as object in sentence, that's mean as second personal pronoun (singular) Form of personal pronoun "he" it is a subject in sentence that refer to man or boy, that's mean as third personal pronoun (singular).

Form of personal pronoun "him" it is a object in sentence that refer to man or boy, that's mean as third personal pronoun (singular).

Form of personal pronoun "she" it is a subject in sentence that refer to women or girl, that's mean as third personal pronoun (singular).

Form of personal pronoun "her" it is a object in sentence that refer to women or girl, that's mean as third personal pronoun (singular.

Form of personal pronoun "we" It's function as a subject in sentence that's mean as first personal pronoun (plural). 
Form of personal pronoun "us" it's function as object in sentence that's mean as first personal pronoun (plural).

Form of personal pronoun "you" it's function as subject or objet in sentence that's mean as second personal pronoun (plural)

Form of personal pronoun "they" it is function as a subject in sentence. That's mean as third personal pronoun (plural)

Form of personal pronoun "them" it is function as object in sentence that's mean as third personal pronoun (plural).

2. Forms, function and how using of personal pronoun in Bima language.

Forms, of personal pronoun"Mada, Ndaiku, wekiku" that's mean "I or me" it is a fine pronoun or polite is used by the younger to the older and also used in formal situation ex; daughter or son to theirs parents, students to theirs teacher until also person to foreign people. That isFunction as subject and object in sentences. Its meaning first personal pronoun (singular)

Forms of personal pronoun "Nahu" that's mean "I or me" it is a rough pronoun that just used to friends of the same age ex; your classmate or best friend. That is function as subject and object in sentences. Its meaning first personal pronoun (singular).

Forms of personal pronoun "Nggomi,Nggou" that's mean "you" it is a rough pronoun that just used to friends of the same age or also is used by the older to the younger ex; the parents to their children and someone to friend.That function as subject and object in sentence Its meaning second personal pronoun (singular)

Forms of personal pronouns " ita, ndaita, ndaimu" that's mean "you" it is fine pronoun or polite that is used by the younger to the older and even friend to friend ex; kids to their mother, friend to their classmate or their best friend and also people to the foreign people. That function as subject and object in sentence Its meaning second personal pronoun (singular).

Form of personal pronoun "sia" that's mean "he or she and him or her" that function as subject and object in sentence its meaning third personal pronoun (singular)
Form of personal pronoun "Nami" that's mean "We and us" that function as subject and object in sentence. It is used by friends of the same age its meaning first personal pronoun (plural).

Form of personal pronoun "madadoho" that's mean "we and us" that function as subject and object in sentence. It is used by the younger to the older ex: students to their teacher its meaning first personal pronoun (plural)

Form of personal pronoun "Nggomidoho, Ndaidohomu" that's mean "you" that function as subject and object in sentences it is used by the friends of the same age or is used by the older to the younger its meaning second personal pronoun (plural)

Form of personal pronoun "Itadoho, Ndaidohota" that's mean "you" that function as subject and object in sentences it is used by the younger to the older its meaning second personal pronoun (plural)

Form of personal pronoun "SiaDoho" that's mean "them" that function as subject and object in sentence its meaning third personal pronoun (plural)

In Bima language personal pronoun that was added clits (doho) such as, Nggomi, mada, ita, ndai, and sia (singular) + doho would be form of pluralpersonal pronoun except "Nami" that's meaning "we and us"

\section{Similarities of personal pronoun in} English and Bima language

In English and Bimalanguage the forms of personal pronouns are divide based on number of types and function such as, in English the typesare divided become two these are singular and plural likewise In Bima language.

They also have more similarities such as their function are divided become 3 that are

(I) first personal pronoun

(2)second personal pronoun , and

(3) Third personal pronoun.

4. Differences of personal pronoun in English and Bima Language

Using forms personal pronoun in English be distinguished based on subject and object example, "I"( subject)would be changed "Me" (object )if arranged in 
sentences of passive Does the sentence passive or active. While in Bima language is not distinguished using them and form of word isn't changed for example: "nahu" as subject or object isn't like in English "I" became "me".

In Bima language changed and using the forms of personal pronouns based on who are we talking to and how is the situation an example, using first personal pronoun "nahu" will canged be "mada" if we were talking to who are the older..

In English personal pronouns of third personal pronoun are distinguished based on gender like man or woman for example: "he or him" (man) and "she or her" (woman). While in Bimalanguage it is not differentiated based on gender, for example"sia (he and she)" this refer to third personal pronoun, whether female or male, the use is the same, unlike English which distinguishes the two based on gender.

Using personal pronoun in Bimaare depend on situation, class, relationship of culture, and relation of family.

\section{KESIMPULAN}

Personal pronouns in English was not influenced by culture system exception to third personal pronoun which distinguished based on male and Female. Personal pronoun in English would be changed from subject to object. While in Bima change the form of personal pronoun are differentiated from situation, and who are talking to.

In Bima language using personal pronoun was not difficult and change from singular personal pronoun to plural because in Bima only add a clit so that will change a meaning for Example: " nggomi" that's mean you (singular\} if form of "nggomi" added "doho" (clit) became "nggomidoho"( you) in the meaning plural. As well as with other pronouns except"nami"'is a first plural personal pronoun that is not influenced by clit and rather is formed naturally.

\section{REFERENCES}

Arts and Arts. 1982. English Syntactic Structure: Function and Category in

Jurnal Ilmu Sosial dan Pendidikan
Sentence Analysis. Oxford: Pergamon Press.

Bloomfield, Leonard. 1933. Language, London: The University Of Chicago Press.

Bungin,M. 2010. Penelitian kualitatif, Jakarata: Kencana.

Debdikbud, 1996 Fonologi Bahasa Bima, Jakarta: perpustakaa npusat pengembangan dan pembinaan bahasa. Departemen Pendidikan dan Kebudayaan

Jafar, Syamsinas.2004. "Sistem Sapaan Bahasa Bima: Kajian Makna Penghormatan Dan Solidaritas". Tesis. Denpasar: Universitas Udayana.

Nababan,P.W.J.1983. Division of structures, Content, Method sand Techniques of Education.Paris:Unesco Press

Naranmasse. 2010. "Kata ganti orang dalam bahasa Inggris dan Bahasa Tanimbar"Suatu Analisis Konstraktif. Skripsi Fakultas Sastra Unstrat. 